\title{
Constitutive Secretion of Protease Nexin-1 by Glial Cells and Its Regulation by G-Protein-Coupled Receptors
}

\author{
Ronald Giau, Josiane Carrette, Joël Bockaert, and Vincent Homburger \\ Unité Mixte de Recherche, Centre National de la Recherche Scientifique 5203, U 661 Institut National de la Santé et de la Recherche Médicale, Universités \\ Montpellier I and II, and Institut de Génomique Fonctionnelle, F-34094 Montpellier Cedex 5, France
}

\begin{abstract}
Extracellular serine proteases and their inhibitors (serpins) play a key role for synaptic plasticity in the developing and adult CNS. Serpins also counteract the extravasated proteases during brain injury. We studied the mechanisms by which one of the most important serpins, serpinE2 or protease nexin-1 (PN-1), is secreted by glial cells and how its secretion is regulated by extracellular signals. Using time-lapse videomicroscopy and biochemical methods, we demonstrate that PN-1 is constitutively secreted through small vesicles animated by a discontinuous movement using microtubules as tracks. The F-actin network underneath the plasma membrane acting as a barrier hindered PN-1 vesicle exocytosis. Vasointestinal/pituitary adenylate cyclase peptides and the G-protein activator mastoparan increased $\mathrm{PN}-1$ secretion by disrupting the F-actin barrier. The receptor-mediated regulation of $\mathrm{PN}-1$ constitutive secretion may be an important mechanism adapting extracellular proteolytic activity to synaptic activity.
\end{abstract}

Key words: secretion; protease; glia; fluorescence; control; VIP

\section{Introduction}

Glial cells and, in particular, astrocytes play a critical role in neuronal nutrition, guidance, homeostasis, and detoxification (Barres, 2003). They provide a structural support and a source of regulatory molecules (Araque and Perea, 2004), neurotrophic factors, and neuropeptides (Lafon-Cazal et al., 2003; Slezak and Pfrieger, 2003). Moreover, astrocytes actively control synaptogenesis (Slezak and Pfrieger, 2003; Ullian et al., 2004), synaptic efficacy, and plasticity (Pfrieger and Barres, 1997; Murai et al., 2003). In this regard, it has been proposed that glia-derived soluble proteins are necessary for the synapse formation and function (Blondel et al., 2000; Slezak and Pfrieger, 2003). However, little is known about the components of the intracellular secretory pathways through which these proteins transit and ultimately exit the astrocytes.

Astrocytes possess machinery for vesicular fusion that transport and secrete these neuroactive proteins (Volknandt, 2002). Cultured hippocampal astrocytes secrete secretogranin II (Calegari et al., 1999), and cortical astrocytes discharge atrial natriuretic peptide (Krzan et al., 2003) in a $\mathrm{Ca}^{2+}$-dependent manner, suggesting that these cells possess a regulated secretory pathway.

Received Feb. 6, 2004; revised July 15, 2005; accepted July 18, 2005.

This work was supported by a grant from the French Association Against Cancer and a grant from the Centre National de la Recherche Scientifique. We thank Dr. Monard for his kind gift of anti-PN-1 antibodies. We acknowledge Laurent Guillou for peptide synthesis; Alain Carrette for designing and building a thermal-controlled chamber; Nicole Lautrédou and Pierre Travo for their help with confocal imaging and deconvolution, respectively; Claude Tougard, Thierry Durroux, Marie-Laure Parmentier, Mireille Lafon, and Gyslaine Bertrand for helpful suggestions; Philippe Marin for providing some astrocyte cultures and constant encouragement; and Angie Turner-Madeuf for critical reading of this manuscript. We thank Mireille Passama and Laurent Charvet for skillful preparation of photographs and figures.

Correspondence should be addressed to Vincent Homburger, Institut de Génomique Fonctionnelle, 141 Rue de la Cardonille, F-34094 Montpellier Cedex 5, France. E-mail: vhomburger@igf.cnrs.fr.

DOI:10.1523/JNEUROSCI.2430-05.2005

Copyright $\odot 2005$ Society for Neuroscience $\quad$ 0270-6474/05/258995-10\$15.00/0
Dense core and clear electron-lucent vesicles have also been identified in cultured astrocytes (Calegari et al., 1999). This raises the possibility that astrocytes contain several types of vesicles involved in the release of various neurotransmitters, peptides, or proteins (Bezzi et al., 2004).

Glial and neuronal cells possess their own serine proteasesignaling system, including many components of the blood coagulation and fibrinolysis systems (i.e., thrombin or plasmin) as well as unique members of the serpin class (i.e., neuroserpin) (Turgeon and Houenou, 1997; Gingrich and Traynelis, 2000). Cumulative evidence has shown that the balance between extracellular serine proteases and their cognate serpins may be involved in the development (Turgeon and Houenou, 1997), plasticity (Tomimatsu et al., 2002), and pathology of the nervous system (Turgeon and Houenou, 1997; Molinari et al., 2003). Moreover, these proteases and their inhibitors may also play a role when the blood-brain barrier is compromised (Gingrich and Traynelis, 2000).

Protease nexin-1 (PN-1) or serpinE2 is a $43 \mathrm{kDa}$ glycoprotein synthesized and released by both glial and neuronal cells (Reinhard et al., 1994). PN-1 belongs to the serpin family (Gloor et al., 1986) and inhibits several serine proteases, including thrombin (Baker et al., 1980; Knauer et al., 2000). In cell cultures, PN-1 promotes neurite outgrowth by preventing the cleavage-induced activation of thrombin receptors (Gurwitz and Cunningham, 1988; Suidan et al., 1992). Together with thrombin, PN-1 plays a role in neuronal degeneration or protection (Smith-Swintosky et al., 1995; Vaughan et al., 1995). In mice, both overexpression and inactivation of $\mathrm{PN}-1$ alter hippocampal long-term potentiation (Luthi et al., 1997), and overexpression leads to a progressive neuronal and motor dysfunction (Meins et al., 2001).

To better understand the mechanisms that underlie the trafficking and secretion in astrocytes, we focused on the traffic and 
exocytosis of PN-1 using a green fluorescent protein (GFP)-tagged-PN-1 (GFP/ $\mathrm{PN}-1$ ). The post-Golgi biosynthetic traffic of GFP/PN-1 was studied by time-lapse imaging, fluorescence and biochemical quantitations, and dual imaging in C6 glioma cells and cultured astrocytes.

\section{Materials and Methods}

Plasmid constructions. The GFP/PN-1 construction was obtained by inserting GFP between the signal peptide (SP-PN-1; aa 1-20) and the mature PN-1 (aa 21-408) in a threestep process. First, SP-PN-1 was amplified using appropriate primers. Second, the mature $\mathrm{PN}-1$ sequence was amplified and linked to the $3^{\prime}$ of the SP-PN-1. Third, the GFP sequence was amplified from pEGFP-N1 (Clontech, Cambridge, UK) with two glycine residues and HindIII restriction sites flanking either ends (5'-HindIII-GlyGly-EGFP-GlyGly-HindIII $\left.3^{\prime}\right)$. The modified sequence of GFP was then incorporated into the $\mathrm{PN}-1$ sequence.

The $\beta$-tubulin/DsRed construction was obtained by fusing the red fluorescent protein (DsRed) from Discosoma sp. in pDsRed vector (Clontech) to the $3^{\prime}$ of the $\beta 5$-tubulin. Tubulin was amplified by PCR without the stop codon and linked to the $5^{\prime}$ of the full open reading frame of DsRed. The fused product was then subcloned in the pEGFP-N1 vector lacking the EGFP gene. All of the constructs were confirmed by sequencing.

Cell culture and transfections. C6 glioma cells were cultured as described previously (Lagriffoul et al., 1996). For transient or stable transfections, subconfluent cells were incubated with different plasmid constructions and Exgen 500 reagent (Euromedex, Strasbourg, France) following the instructions of the manufacturer. Cells were used $48-72 \mathrm{~h}$ after transfection. To create stable cell lines, transfected

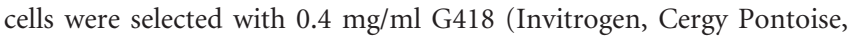
France), and neo-resistant populations expressing GFP/PN-1 were enriched by cell sorting using a fluorescence-activated cell sorting analyzer (Beckman Instruments, Villepinte, France). Thereafter, they were cultured in medium supplemented with $0.4 \mathrm{mg} / \mathrm{ml} \mathrm{G} 418$.

Striatal astrocytes were cultured as described previously (el-Etr et al., 1989) and transfected with lipofectamine plus reagent (Invitrogen) following the instructions of the manufacturer and maintained in medium for $48-72 \mathrm{~h}$ before experiments.

Antibodies and reagents. Mouse monoclonal antibodies against PN-1 (4B3) were a kind gift from Dr. D. Monard (Friedrich Miescher Institut, Basel, Switzerland) and have been described previously (Reinhard et al., 1994). For detection of GFP, we used monoclonal antibodies from Roche Diagnostics (Meylan, France) To stain F-actin, we used rhodaminelabeled phalloidin, and to label microtubules, we used anti-tubulin antibodies (all were obtained from Sigma, St. Louis, MO). Monoclonal antibodies against trans-Golgi network-38 (TGN38) and $\gamma$-adaptin were obtained from BD (Le Pont de Claix, France). To disrupt microtubule, we used nocodazole (Fluka, Saint Quentin Fallavier, France), and to induce F-actin disassembly, we used cytochalasin D (Sigma) or latrunculin B (Calbiochem, La Jolla, CA). Jasplakinolide was obtained from Invitrogen. Mastoparan (Mp) was synthesized, as described previously (Lagriffoul et al., 1996), or supplied from Calbiochem. Plasmid encoding for enhanced yellow fluorescent protein (EYFP)-tagged $\beta$-actin (EYFP/ actin) was obtained from Clontech. Vasoactive intestinal peptide (VIP) and pituitary adenylate cyclase-activating polypeptide with 38 amino acids (PACAP-38) were obtained from Neosystem (Strasbourg, France), and Bordetella pertussis toxin (PTX) was obtained from Sigma.

Drug treatment and imaging. Before analysis, stable transfected cells were incubated in the presence of $5 \mathrm{~mm}$ sodium butyrate (Sigma) for $18 \mathrm{~h}$ to increase GFP/PN-1 expression by enhancing transcription of cytomegalovirus promoter-controlled genes (Dorner et al., 1989). Blocks of $20^{\circ} \mathrm{C}$ were performed in the medium supplemented with 20 mM HEPES, $\mathrm{pH} 7.4$, and $50 \mu \mathrm{g} / \mathrm{ml}$ cycloheximide, a concentration sufficient to block protein synthesis by $>95 \%$. Shifting temperature after the $20^{\circ} \mathrm{C}$ block was performed by changing medium and incubating cells at $37^{\circ} \mathrm{C}$ in the medium, without HEPES. Imaging of live cells was performed on a Zeiss (Le Pecq, France) Axiovert $100 \mathrm{TV}$ inverted microscope at $34^{\circ} \mathrm{C}$ to slightly reduce vesicle motion. The microscope was equipped with a software-driven filter wheel, a $63 \times$ oil immersion objective [ 1.3 numerical aperture (NA); Zeiss], or a $25 \times$ oil immersion objective $(0.8 \mathrm{NA}$; Zeiss). A homemade temperature-regulated chamber perfused by a syringe pump (Harvard Apparatus, Holliston, MA) at $100 \mu \mathrm{l} / \mathrm{min}$ and a MicroMax 1300 charge-device camera (Princeton Instruments, Evry, France) driven by MetaMorph imaging software (version 4.17; Universal Imaging Corporation, West Chester, PA) were used for cell imaging. Filter sets for conventional fluorescein imaging and neutral density filters were used for GFP/PN-1. For $\beta$-tubulin/DsRed, we used filters (Omega Optical, Brattleboro, VT) with a $540 \pm 25 \mathrm{~nm}$ bandpass and a $575-\mathrm{nm}$ long bandpass for excitation and emission, respectively, and for YFP/ actin, we used $500 \pm 25$ and $545 \pm 35 \mathrm{~nm}$ bandpass filters for excitation and emission, respectively.

For time-lapse imaging of both GFP/PN-1 and $\beta$-tubulin/Dsred, molecules were excited with a $500 \pm 25 \mathrm{~nm}$ bandpass filter and imaged with a $530 \mathrm{~nm}$ long-pass emission filter. For time-lapse imaging of both GFP/ $\mathrm{PN}-1$ and EYFP/actin, molecules were excited with a $475 \pm 40 \mathrm{~nm}$ bandpass filter and imaged with a $535 \pm 45 \mathrm{~nm}$ filter. Exposure times were $300-500 \mathrm{~ms}$ for GFP/PN-1, 0.5-1 s for DsRed, and $500 \mathrm{~ms}$ for YFP/actin. Images from the MicroMax camera were converted to TIFF files that were edited using NIH Image 1.62 and compiled into QuickTime (Apple Computers, Cupertino, CA) movies with Premiere 6.0 (Adobe Systems, San Jose, CA). 
a

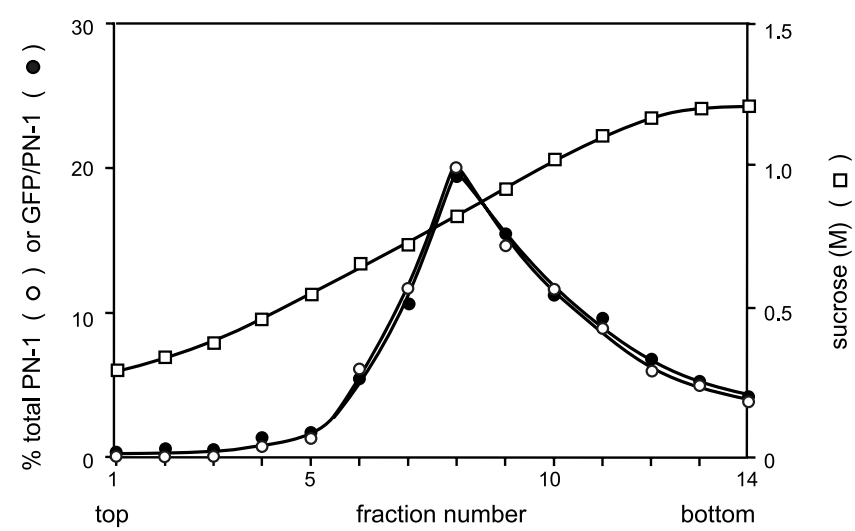

b

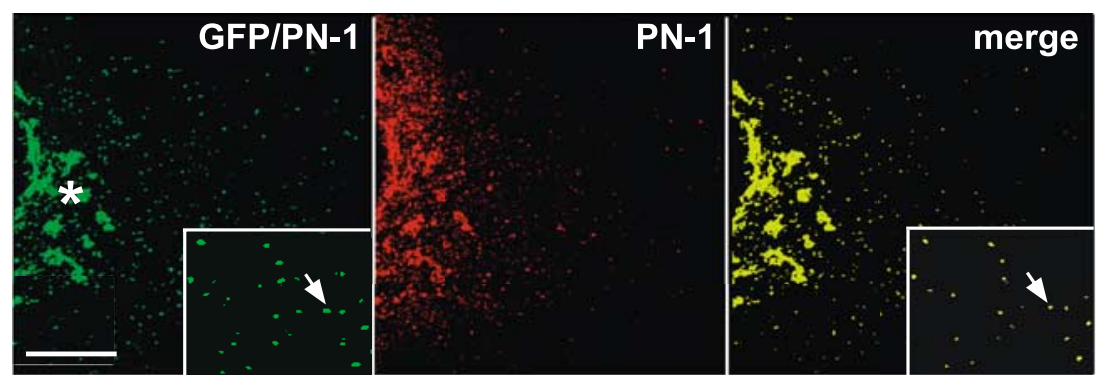

C

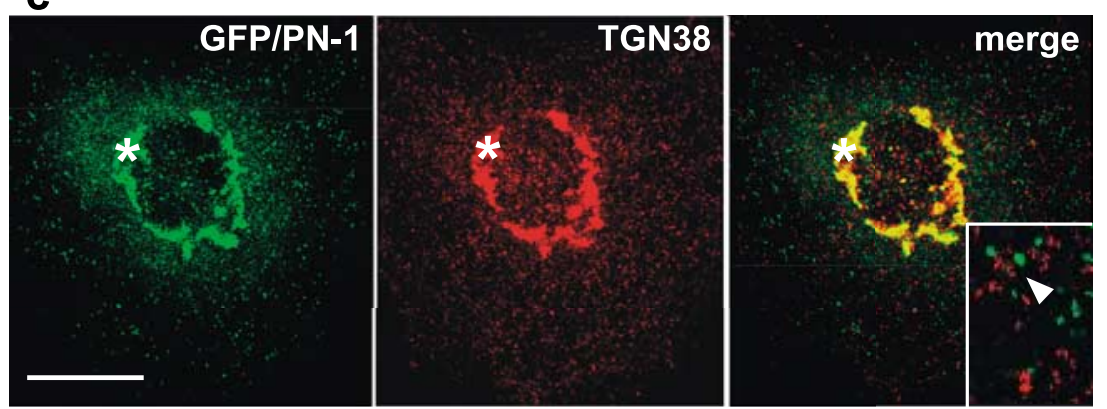

Figure 2. Colocalization of GFP/PN-1 and PN-1 or TGN38. $\boldsymbol{a}$, Sucrose equilibrium gradient analysis of relative densities of vesicles containing GFP/PN-1 and endogenous PN-1. A density sucrose gradient representative of three independent experiments is shown. $\boldsymbol{b}$, C6 cells expressing GFP/PN-1 were analyzed by confocal microscopy for GFP fluorescence or PN-1 immunostaining. Colocalization was seen both in the perinuclear region (asterisk; $87 \%$ colocalized) and in vesicles (inset, arrow; $99 \%$ colocalized). Scale bar, $10 \mu \mathrm{m}$. c, GFP/PN-1 and TGN38 are transported by different carriers. Colocalization was seen in the perinuclear region (asterisk; 97\% colocalized) but not in vesicles at the cell periphery (inset, arrowhead; 2\% colocalized). Scale bar, $20 \mu \mathrm{m}$.

Quantitative fluorescence measurements. The rate of GFP/PN-1 exit from the Golgi/TGN area was determined by measuring GFP/PN-1integrated fluorescence intensity in the TGN over time (10 min intervals; 120 min duration). Using the $25 \times$ objective, we measured the entire cell fluorescence intensity by imaging in a single focal plane and applied thresholds to delineate Golgi-associated GFP/PN-1, as described previously (Kreitzer et al., 2000). Threshold values selected at the first time point in each recording were maintained constant for all images. Data were normalized as a percentage of TGN-associated fluorescence, and at time 0 was set to 100 . Loss of fluorescence associated with the Golgi/TGN region was not the result of photobleaching, because the total fluorescence over time remained constant when identical imaging conditions were used in fixed cells.

Vesicle number was calculated on fixed cells by segmenting the 12-bit image and determining the number of objects using a macro routine of the MetaMorph software. Objects having an area between two and seven pixels were considered to be vesicles.

Vesicle elementary speeds were determined using a macro routine of MetaMorph software. Data regarding X-and Y-position coordinates and vesicle displacement were logged to disk and treated with Excel Software (Microsoft, Seattle, WA).

F-actin distribution was determined using a $25 \times$ objective after $\mathrm{F}$-actin staining by rhodamine phalloidin (RP) and nucleus staining by Hoechst 33258. Images of equatorial slices were quantified by radial line scan analysis. Two to three lines per cell (on at least 30 cells) were obtained, each extending from the exterior to the nucleus. The nucleus was normally $>8 \mu \mathrm{m}$ from the cell edge and, therefore, not included in the analysis. The RP fluorescence intensity profiles for each experiment were pooled and averaged to form a mean profile.

Deconvolution. Stacks of 12-bit files from time-lapse acquisition and images captured by conventional or confocal microscopy were restored with Huygens (Scientific Volume Imaging, Hilversum, The Netherlands). Restored stacks and images were then further processed with Imaris (Bitplane, Zurich, Switzerland).

Indirect immunofluorescence. Cell cultures generated on $12 \mathrm{~mm}$ glass coverslips were dealt with as described previously (Lagriffoul et al., 1996). For PN-1 antibodies, cells were permeabilized with $0.4 \%$ SDS in $1.5 \mathrm{~m}$ Tris- $\mathrm{HCl}, \mathrm{pH}$ 8.8 , to allow antibody access to GFP/PN-1 into the vesicle lumen, as described previously for PN-1 (Reinhard et al., 1994). Cells were viewed on a Zeiss Axiophot 2 microscope or on a BioRad (Hercules, CA) MRC 1024 confocal laserscanning microscope equipped with an argon/ krypton ion laser. Colocalization analysis was processed by the colocalization Bio-Rad Lasersharp software on individual confocal optical sections using the facilities of the Centre Régional d'Imagerie Cellulaire (Montpellier, France).

Subcellular fractionation. Cells subjected to the temperature-induced block $\left(2 \mathrm{~h}\right.$ at $20^{\circ} \mathrm{C}$ and $30 \mathrm{~min}$ at $37^{\circ} \mathrm{C}$ ) were washed and homogenized in $0.25 \mathrm{~m}$ sucrose containing $20 \mathrm{~mm}$ HEPES, $\mathrm{pH}$ 7.4, 1 mm EGTA, and $1 \mathrm{~mm}$ magnesium acetate supplemented with a mixture of protease inhibitors $(1 \mu \mathrm{g} / \mathrm{ml}$ aprotinin, $2 \mu \mathrm{M}$ leupeptin, $60 \mu \mathrm{M}$ benzamidine, and $3 \mu \mathrm{m}$ antipain) using a cell Cracker (EMBL, Heidelberg, Germany). After centrifugation for $10 \mathrm{~min}$ at $1000 \times \mathrm{g}$, the supernatant was loaded onto a $0.3-1.2 \mathrm{M}$ continuous sucrose gradient in $20 \mathrm{~mm}$ HEPES, $\mathrm{pH} 7.4$ (velocity gradient), and centrifuged for $15 \mathrm{~min}$ at $106,000 \times \mathrm{g}$ in a swingout rotor (SW41; Beckman Instruments). The first four fractions from the top of the gradient were loaded onto a $0.5-1.6 \mathrm{M}$ continuous sucrose gradient in $20 \mathrm{~mm}$ HEPES, pH 7.4 (density gradient), and centrifuged for $20 \mathrm{~h}$ at $106,000 \times \mathrm{g}$. Fractions were collected and centrifuged for $1.5 \mathrm{~h}$ at $150,000 \times g$ in a TL-100 centrifuge (Beckman Instruments). Aliquots of resuspended pellets were analyzed by SDS-PAGE and immunoblotting.

Quantitative analysis of PN-1 secretion. Cultured cells in 12-well plates were subjected to the temperature block $\left(20^{\circ} \mathrm{C}\right)$ in serum-free DMEM supplemented with $20 \mathrm{~mm}$ HEPES, $500 \mathrm{mg} / \mathrm{L}$ chicken ovalbumin, and $50 \mu \mathrm{g} / \mathrm{ml}$ cycloheximide. Bordetella pertussis toxin cell treatments were performed as described previously (Lagriffoul et al., 1996). Secretion experiments were performed at $37^{\circ} \mathrm{C}$ in the same medium but without HEPES. Media and cells from triplicate wells were harvested, centrifuged, and frozen at $-80^{\circ} \mathrm{C}$. Aliquots of $30 \mu \mathrm{l}$ from C6 cells ( $15 \mu \mathrm{g}$ and $20-30 \mu \mathrm{g}$ of protein for media and lysates, respectively) and $70 \mu \mathrm{l}$ from striatal astrocytes ( $35 \mu \mathrm{g}$ protein, precipitated for $2 \mathrm{~h}$ with $10 \%$ ice-cold trichloroacetic acid) were subjected to SDS-PAGE analysis and immunoblotting with monoclonal anti-GFP or 
anti-PN-1 antibodies as described previously (Lagriffoul et al., 1996; Lafon-Cazal et al., 2003). Detection was performed by chemiluminescence, and signals were quantified by densitometric analysis. Data were processed for mean \pm SEM and Student's $t$ test.

\section{Results}

Expression and localization of GFP/PN1 in glial cells

We tagged a rat $\mathrm{PN}-1$ at its mature $\mathrm{N}$ terminus with GFP (GFP/PN-1) and transiently transfected this construct in C6 glioma cells (a transformed rat astroglial cell line) and primary cultures of striatal astrocytes (Fig. 1). In lysates from transfected C6 glioma cells, GFP/PN-1 displayed the expected apparent molecular mass $(\sim 70 \mathrm{kDa})$ and recognition by antibodies raised against GFP or PN-1 (Fig. $1 b)$. Note that transfected cells express similar amounts of GFP/PN-1 and PN-1 (ratio, 1.8:1). Conventional microscopy indicated that GFP/PN-1 was localized in the secretory pathway (TGN and transport vesicles) (Fig. 1d,e, asterisks and arrows, respectively) of C6 glioma cells and astrocytes. At the cell periphery, the punctuated GFP fluorescence mainly colocalized with PN-1 staining (Fig. $2 b$, inset, arrows). Furthermore, GFP/PN-1 and PN-1 sedimented in the same fractions on density sucrose gradients (Fig. 2a). This indicates that GFP/PN-1 and $\mathrm{PN}-1$ were sorted and transported in the same vesicles.

Western blot analysis of conditioned media from transfected cells indicated that GFP/PN-1 was efficiently secreted (Fig. 1c). Furthermore, GFP/PN-1 secretion was enhanced by mastoparan (Fig. 1c), an activator of heterotrimeric Gi/Go-proteins (Higashijima et al., 1990), as reported previously for PN-1 secretion (Lagriffoul et al., 1996). In contrast, mastoparan 17, an inactive analog of mastoparan, did not significantly stimulate GFP/PN-1 secretion (data not shown). Together, these results suggest that GFP/PN-1 could be a good tool to study PN-1 traffic and secretion in astrocytes.

\section{Post-Golgi traffic of GFP/PN-1-containing vesicles}

A stable C6 glioma cell line expressing GFP/PN-1 was established. A transient $20^{\circ} \mathrm{C}$ temperature block induced the accumulation of GFP/PN-1 fluorescence in the perinuclear area (Fig. $2 b, c$, asterisks). An antibody raised against TGN38 stained this area (Fig. 2c); TGN38 is a $38 \mathrm{kDa}$ integral membrane protein that cycles between the TGN and the cell surface (Girotti and Banting, 1996). This area was also stained by an antibody raised against $\gamma$-adaptin (data not shown), a protein from the AP1 complex that cycles between TGN and endosomal compartments. These observations indicate that the perinuclear region in which GFP/ PN-1 colocalized with TGN38 and $\gamma$-adaptin is the TGN (Fig. $2 c$, asterisk).

Shifting the temperature to $37^{\circ} \mathrm{C}$ triggered a synchronous exit of GFP/PN-1-containing vesicles, as shown by dots in Figure 2, $b$ and $c$ (arrows and arrowhead). At the cell periphery, these dots did not exhibit a significant overlap with TGN38 (Fig. $2 c$, inset, arrowhead) and $\gamma$-adaptin (data not shown). This indicated that GFP/PN-1 and TGN38 or $\gamma$-adaptin were transported by different post-Golgi carriers and that segregation in the distribution of GFP/PN-1 and these proteins did occur.

In an attempt to characterize $\mathrm{GFP} / \mathrm{PN}$-1-containing vesicles, we looked to several proteins that are constitutively released by glial cells (transferrin, apoliprotein E, and cystatin C) (Espinosa de los Monteros et al., 1990; Lafon-Cazal et al., 2003). We also looked to TGF- $\beta 2$, a neurotrophic factor released by glial cells that has been shown to be secreted by the regulated secretory pathway in PC12 and hippocampal neurons (Specht et al., 2003). We were able to detect no colocalization of these proteins with $\mathrm{PN}-1 / \mathrm{GFP}$ on post-Golgi vesicles $(<3 \%$ colocalization; $n=$ $10-15$ cells) either in C6 glioma cells or primary striatal astrocytes (data not shown).

Figure 3, $a$ and $b$, displays time-lapse imaging of vesicular budding from TGN (asterisk) in C6 glioma cells. In Figure 3b, images from a sequence showed GFP/PN-1-containing membranes pulling out from a discrete TGN domain as a spherical bud, subsequent to fluorescence accumulation in a restricted area (arrowhead). This ball-like mass detached and moved outward as a separate post-TGN vesicle (Fig. $3 b$, arrowhead) (video 1, available at www.jneurosci.org as supplemental material). 
Acquired images from cell periphery showed a vesicle moving toward the cell edge (Fig. $3 c, d$ ). This vesicle remained stationary for several seconds and then rapidly disappeared (Fig. 3d, arrowhead). Changes in the intensity of vesicle fluorescence were abrupt during fusion at the plasma membrane, because discharged GFP/PN-1 was rapidly dispersed by the continuous flux of cell perfusion. A different vesicle moving from top to bottom remained visible and did not fuse with the plasma membrane (Fig. $3 d$, asterisk) (video 2, available at www.jneurosci.org as supplemental material). Furthermore, careful observations indicated that several fluorescent vesicles disappeared in the same area of the cell, suggesting the putative existence of microdomain for GFP/PN-1 exocytosis (data not shown).

The exit of vesicles containing GFP/PN-1 from the TGN is illustrated by the loss of fluorescence in the Golgi/TGN area (Fig. $3 e$, insets). From the time course of GFP/PN-1 exit (Fig. 3e), half-time and complete draining of TGN can be estimated at $\sim 40$ and $\sim 120 \mathrm{~min}$, respectively. As shown in Figure $3 f$, half-time and maximal GFP/PN-1 secretions were estimated at $\sim 40$ and $\sim 120$ min, respectively. Data from time-lapse imaging of TGN exit, together with those from secretion kinetics, indicated that GFP/ PN-1-containing vesicles that budded from TGN were apparently not stored. They rapidly discharged their content by exocytosis. This was confirmed by the decrease in vesicle number between 30 and 120 min after warm-up (from $301 \pm 17$ to $19 \pm$ 4 vesicles/cell from equatorial planes of 35 cells for each condition). This suggests that GFP/PN-1 secretion by $\mathrm{C} 6$ glioma cells used a constitutive secretory pathway, as we reported previously for PN-1 (Lagriffoul et al., 1996).

Numerous fluorescent vesicles were seen moving out from the Golgi/TGN area on time-lapse sequences (Fig. 4a) (video 3, available at www.jneurosci.org as supplemental material). These vesicles showed brief periods of rapid runs (maximal velocity of $\sim 1$ $\mu \mathrm{m} / \mathrm{s}$ ) interrupted by periods of resting. Thereafter, they continued either in the same direction, changed direction, or reversed their direction (Fig. 4b,c). This stop-and-go movement was observed in C6 glioma cells (video 3, available at www.jneurosci.org as supplemental material) and astrocytes (data not shown). More than $95 \%$ of vesicles ( $95.5 \pm 0.5 \% ; n=1248$ vesicles) moved over long distances $(>5 \mu \mathrm{m}$ ), and $\sim 5 \%$ did not move detectably (maximal value, $\sim 0.25$ $\mu \mathrm{m} / \mathrm{s}$ ) (Fig. $4 c$ ) during the entire period of imaging, generally $1-5$ $\mathrm{min}$. The vesicles moved mainly from the Golgi/TGN area to the cell periphery, as would be expected for a secretory traffic, but some vesicles moved in the opposite direction (Fig. $4 a$ ) (video 3 , available at www.jneurosci.org as supplemental material). Several vesicles were transported along a single track, and some tracks were subjected to a heavy traffic (Fig. 4a) (video 3, available at www. jneurosci.org as supplemental material).

\section{Microtubule-dependent transport of GFP/PN-1}

Numerous GFP/PN-1-containing vesicles were detected along microtubules by confocal imaging of fixed stable transfected C6 cells (Fig. $5 a$, inset, arrows). Microtubule depolymerization by nocodazole induced a decrease in the maximal velocity of vesicles and an inhibition of GFP/PN-1 secretion (Fig. 5b,c). Time-lapse videomicroscopy of both GFP/PN-1 and $\beta$-tubulin/DsRed in transfected cells imaged GFP/PN-1-containing vesicles moving along microtubule tracks and then switching between tracks (Fig. $5 d$, arrow) (video 4, available at www.jneurosci.org as supplemental material). Thus, GFP/PN-1-containing vesicles moved along microtubules, and depolymerization of these tracks by nocodazole decreased transport and secretion of GFP/PN-1.
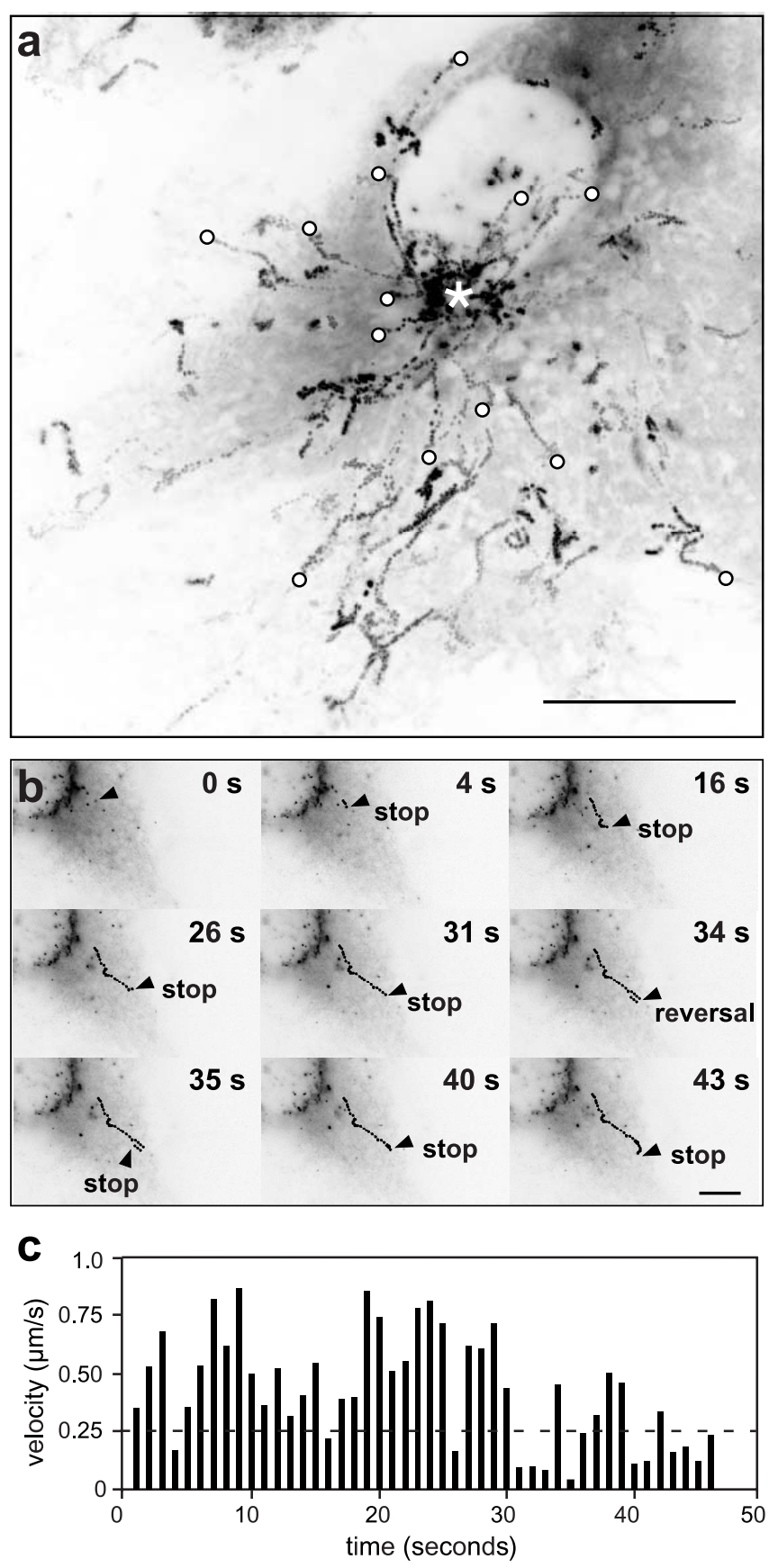

Figure 4. Time-lapse videomicroscopy of GFP/PN-1 post-Golgi traffic. See also video 3 (available at www.jneurosci.org as supplemental material). Sequences were acquired every 1-2 s from stable transfected C 6 glioma cells after a $30-60$ min release from a $20^{\circ} \mathrm{C}$ temperature block. $\boldsymbol{a}$, A single inverted image of a composite-projected merge from an acquired sequence (180 frames) is shown. The dotted lines represent vesicles moving along curvilinear paths from the TGN (white asterisk) to cell periphery or in the opposite direction. The end point of several tracks is indicated with an empty dot and shows that tracks are oriented toward the cell periphery. Scale bar, $15 \mu \mathrm{m}$. $\boldsymbol{b}$, Real-time observation of GFP/PN-1 vesicles and their movement after TGN exit. From the time series ( 0.5 frame/s), selected inverted images display the principal features of movement of single vesicle in live cells. The vesicle (arrowhead) moved on average $\sim 0.5 \mu \mathrm{m} / \mathrm{s}$ and had several stops (at 4, 16, 26, 31, 35, 40, and $43 \mathrm{~s}$ ) and changed direction (at 34 and $36 \mathrm{~s}$ ). The total distance of the run was $\sim 23 \mu \mathrm{m}$ within the $43 \mathrm{~s}$ of observation time. Scale bar, $10 \mu \mathrm{m}$. c, Elementary speed profile of vesicle movement. Vesicles were considered to be actively transported if their elementary velocities were $\geq 0.25 \mu \mathrm{m} / \mathrm{s}$, and breaks were characterized by values below the threshold of $0.25 \mu \mathrm{m} / \mathrm{s}$ (dashed line). The plot shows the speed profile of a representative vesicle deduced from the track pattern illustrated in $\boldsymbol{b}$. 


\section{Role of actin cortex in GFP/PN-1 secretion}

Figure $6, a$ and $b$, shows a confocal optical section through the equatorial plane of C6 cells expressing GFP/PN-1. Actinfilaments, stained red by rhodamine phalloidin, were present primarily at the cell cortex (arrows) and in crisscrossed fibers resembling stress fibers (Fig. $6 a$, asterisks). Green dots corresponding to GFP/ $\mathrm{PN}$-1-containing vesicles were distributed throughout the cytoplasm but appeared to accumulate at the F-actin cell cortex (Fig. $6 a, b$, arrows). Figure $6 c$ displays a single-color image from a cell region showing cortical EYFP/F-actin (arrowheads) and GFP/PN-1-containing vesicles (arrows). The sequence in Figure $6 d$ focused on a single GFP/PN-1-containing vesicle (arrow), moving toward the F-actin cortex, sticking and detaching from this barrier (video 5, available at www.jneurosci.org as supplemental material). This sequence suggested that cortical actin could act as a barrier that hinders the movement of vesicles.

Cytochalasin D or latrunculin B, drugs known to depolymerize F-actin filaments, were able to stimulate GFP/PN-1 secretion (Fig. 6e). Depolymerization of F-actin filaments and, in particular, thinning of cortical F-actin induced by these drugs, were confirmed by rhodamine phalloidin staining in fixed cells (data not shown). Furthermore, cell treatment with $10 \mathrm{~mm}$ butanedione monoxime (BDM), a myosin inhibitor, did not modify secretion (data not shown). This indicates that myosins moving along $\mathrm{F}$-actin tracks are not involved in the transport of GFP/PN1-containing vesicles. Together, these results indicate that disruption of the actin cortex elicited exocytosis and that cortical actin could be considered as a barrier blocking the constitutive exocytosis of GFP/PN-1.

\section{Mastoparan acts at a final step in post- Golgi traffic, promoting GFP/PN-1 vesicle discharge}

Post-Golgi traffic and exocytosis of GFP/ $\mathrm{PN}-1$ were monitored in the presence of mastoparan (Higashijima et al., 1988), because this peptide stimulates GFP/PN-1 secretion (Fig. 1c) and increases the guanine nucleotide exchange activity of heterotrimeric Gi/Go-proteins in C6 cells (data not shown). Mastoparan induced a 1.7-fold decrease in the GFP/PN-1 secretion half-time, from 40 to $23 \mathrm{~min}$ (Fig. 7a). This result suggested that mastoparan could stimulate one or several steps in GFP/PN-1 post-Golgi traffic (vesicle formation, transport, or exocytosis).

To identify these steps, we measured the effect of mastoparan on the TGN exit kinetics by time-lapse imaging, as described in Figure $3 e$. Mp did not modify the slope of kinetics when added 15
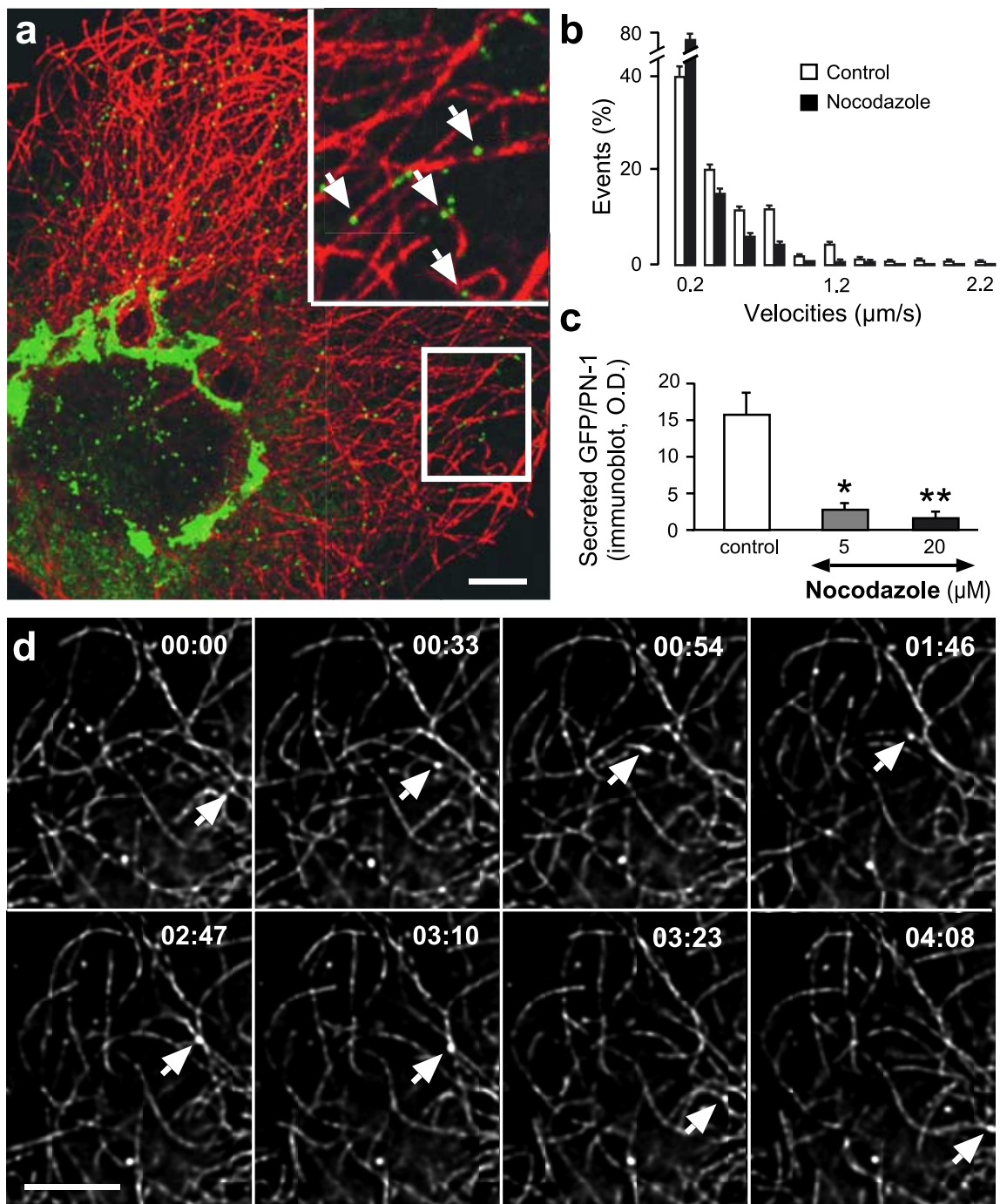

Figure 5. Transport and secretion of GFP/PN-1-containing vesicles are microtubule dependent. $\boldsymbol{a}$, Association of GFP/PN-1 secretory vesicles with microtubules. (6 cells expressing GFP/PN- 1 were stained red with antibodies against $\beta$-tubulin. One scan out of a confocal series is displayed. Inset shows the association of GFP/PN-1 vesicles with microtubules (arrows). Scale bar, $5 \mu \mathrm{m}$. $\boldsymbol{b}$, Maximal velocity inhibition of GFP/PN-1 vesicles by nocodazole. From every cell ( $n=10$ cells), three to five tracks ( 1 frame/s for 1-3 $\mathrm{min}$ ) from displacement of post-TGN vesicles containing GFP/PN-1 were analyzed before and after adding $5 \mu \mathrm{m}$ nocodazole. Velocity profiles were determined by grouping velocities into $0.2 \mu \mathrm{m} / \mathrm{s}$ intervals and then plotted as either control (white bars) or nocodazole (dark bars) events. Data were expressed as the percentage of events in the indicated velocity intervals. The error bars represent SEM. A significant difference between control and nocodazole was obtained in each group ( $p<0.05$; Student's $t$ test). c, Microtubule depolymerization by nocodazole inhibits GFP/PN-1 secretion. Cells were incubated without (control) or with indicated concentrations of nocodazole added $15 \mathrm{~min}$ before the end temperature block and during the 30 min release period. GFP/PN-1 secretion inhibition, representative of three independent experiments, is shown, and error bars represent SEM. Asterisks represent a significant difference compared with control condition ( $t$ test; ${ }^{*} p<0.05$; ${ }^{* *} p<0.01$ ). d, Time-lapse imaging of GFP/PN-1 vesicles moving along microtubules in cells transfected with $\beta$-tubulin/DsRed. See also video 4 (available at www.jneurosci.org as supplemental material). The sequence of deconvolved images $(0.5 \mathrm{frame} / \mathrm{s})$ is displayed at indicated intervals. The arrow indicates movement of a single vesicle along microtubule tracks and switching between tracks. Scale bar, $5 \mu \mathrm{m}$. 0.D., 0ptical density.

min after starting vesicle exit (Fig. 7b). This indicated that budding and fission of GFP/PN-1-containing vesicles from TGN are not targets for mastoparan action. But it may act on later steps in the secretory pathway of GFP/PN1, such as vesicular transport or exocytosis.

To test this hypothesis, cells were incubated for $2 \mathrm{~h}$ at $20^{\circ} \mathrm{C}$ to accumulate GFP/PN-1 in TGN and then shifted to $37^{\circ} \mathrm{C}$ for 30 min to allow the pulse-release of a post-Golgi vesicle pool. Cells were finally returned to $20^{\circ} \mathrm{C}$ to block further formation of vesicles from TGN. As shown in Figure $7 c$, decreasing the temperature from 37 to $20^{\circ} \mathrm{C}$ induced an enhancement of the secretion 

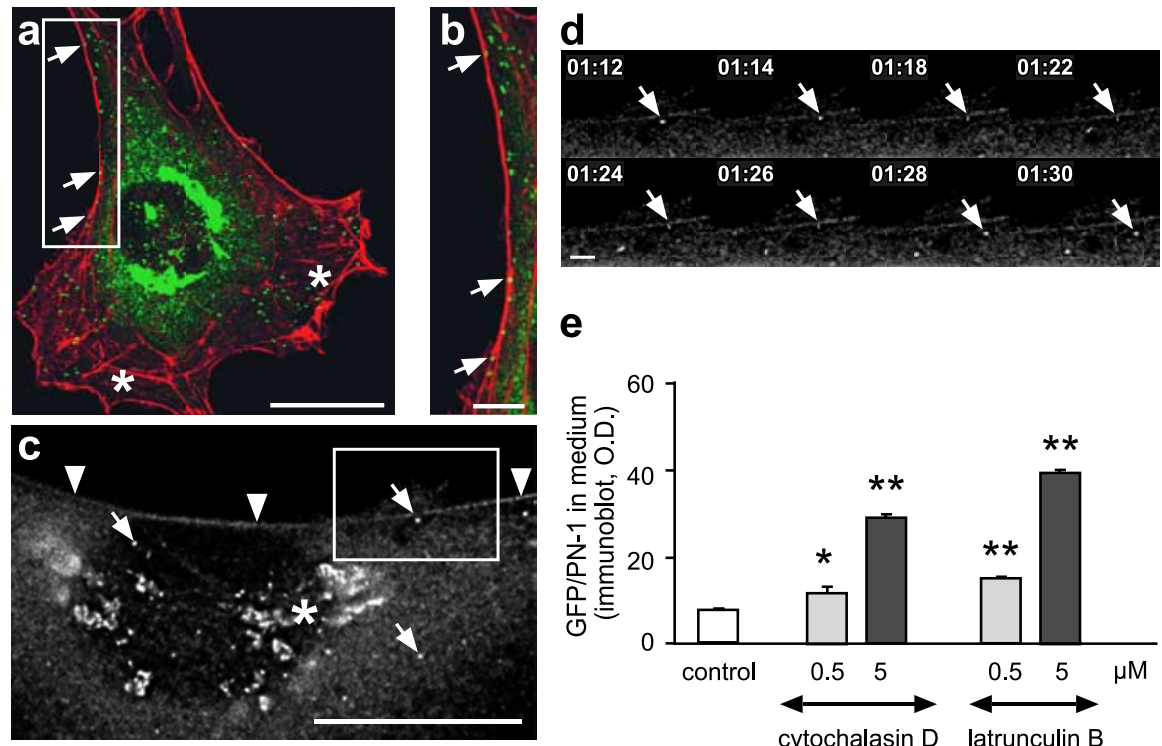

e

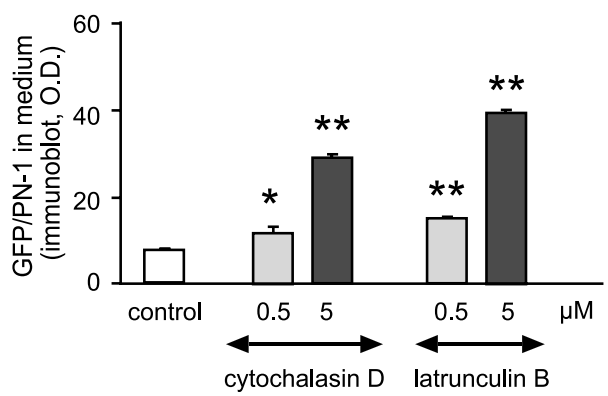

Figure 6. Secretion of GFP/PN-1 is dependent on cortical F-actin disruption. $\boldsymbol{a}, \boldsymbol{b}$, Association of GFP/PN-1 secretory vesicles with cortical actin filaments. Cells were stained with rhodamine-labeled phalloidin. One scan out of a confocal series is displayed. Numerous vesicles transporting GFP/PN-1 (green) are associated with F-actin (red) at the cell cortex (arrows) but not in the cytoplasm (white asterisks). Scale bars: $\boldsymbol{a}, 20 \mu \mathrm{m} ; \boldsymbol{b}, 5 \mu \mathrm{m}$. $\boldsymbol{c}$, $\boldsymbol{d}$, Time-lapse imaging of GFP/PN-1 vesicles and EYFP/actin dynamics in double-transfected cells. See also video 5 (available at www.jneurosci.org as supplemental material). c, A single frame displays EYFP/F-actin at the cell cortex (arrowheads), GFP/PN-1 in Golgi/TGN (white asterisk), and vesicles (arrows). $\boldsymbol{d}$, Cortical F-actin acts as a barrier that hinders the movement of a GFP/PN- 1 vesicle. The sequence of deconvolved images ( $0.5 \mathrm{frame} / \mathrm{s})$ is displayed at indicated time intervals. The arrow indicates movement of a single vesicle toward F-actin cortex, sticking and detaching from this barrier. Scale bars: $\boldsymbol{c}, 20 \mu \mathrm{m} ; \boldsymbol{d}, 1 \mu \mathrm{m}$. $\boldsymbol{e}$, F-actin depolymerization stimulates GFP/PN-1 secretion. Cells were incubated with indicated concentrations of cytochalasin D and latrunculin B, added 5 min before the end of block at $20^{\circ} \mathrm{C}$ and during the 30 min release period, or without (control). GFP/PN-1 secretion stimulation, representative of three independent experiments, is shown, and error bars represent SEM. Asterisks represent a significant difference compared with control condition ( $t$ test; ${ }^{*} p<0.05$; $\left.{ }^{* *} p<0.01\right)$. 0.D., Optical density.

half-time in control conditions (from 40 to $108 \mathrm{~min}$ ). This is attributable to a slowing down of vesicle transport or fusion. However, in these conditions, mastoparan was still able to induce a decrease in the secretion half-time, from 108 to $67 \mathrm{~min}$, indicating that it accelerates GFP/PN-1 vesicular transport, or exocytosis, or both.

Mastoparan did not alter the mean velocities of GFP/PN-1containing vesicles (Fig. 7d), suggesting that it does not act on microtubules or microtubule-associated motors. However, we noticed that the vesicle number per cell decreased in mastoparantreated cells from $320 \pm 25$ to $157 \pm 13$ vesicles/cell (30 min after warm-up, from equatorial planes of 32 cells for each condition). This suggests that vesicle lifetime is reduced as a consequence of exocytosis facilitation by mastoparan.

Mastoparan induces disassembly of cortical F-actin, promoting exocytosis of GFP/PN-1-containing vesicles Changes in F-actin distribution were analyzed and quantified by radial line scanning of rhodamine phalloidin labeling. Cell cortex and interior were designed as regions encompassed by pixel numbers 1-12 and 13-30, respectively. A twofold decrease in rhodamine phalloidin labeling at the cell cortex was induced by mastoparan (Fig. 7e). Jasplakinolide, a stabilizer of preexisting F-actin filaments, inhibited mastoparan-induced GFP/PN-1 secretion (Fig. 7f). Together, these results indicate that mastoparan induces cortical actin remodeling, promoting the access of GFP/ $\mathrm{PN}$-1-containing vesicles to the plasma membrane.
Activation of VPAC receptors induces GFP/PN-1 or PN-1 secretion

Because VIP has been described as a neurotrophic-releasing agent for astrocytes, we wondered whether activation of VIP/PACAP receptors stimulates secretion of GFP/PN-1 or PN-1 from C6 cells and astrocytes. As shown in Figure $8 a$, PACAP induced a dose-dependent secretion of GFP/PN-1 with an $\mathrm{EC}_{50}$ value of 20 $\mathrm{nM}$ and a maximal stimulation of $100 \mathrm{~nm}$. The same maximal stimulation was obtained with $100 \mathrm{nM}$ VIP, indicating that GFP/PN-1 secretion was stimulated via VPAC and not PAC receptors in C6 cells. Cell pretreatment with $B$. pertussis toxin, which ADP-ribosylated heterotrimeric G-proteins such as Gi/Go was able to completely block PACAP-induced GFP/ PN-1 secretion (Fig. $8 b$ ). This indicates that VPAC receptors coupled to $\mathrm{Gi} / \mathrm{Go}-$ proteins are involved in the control of GFP/PN-1 secretion.

The stabilizer of F-actin filaments, jasplakinolide, inhibited GFP/PN-1 secretion induced by PACAP (Fig. $8 c$ ) or VIP (data not shown) in a dose-dependent manner. This indicates that activation of VPAC receptors induced F-actin depolymerization, promoting the access of GFP/ $\mathrm{PN}$-1-containing vesicles to the plasma membrane and the discharge of their content. Furthermore, stimulation with 100 nM PACAP or VIP (data not shown) induced PN-1 secretion in either C6 or striatal astrocytes (Fig. 8d), indicating that secretion of endogenous $\mathrm{PN}-1$ is also regulated as GFP/PN-1 by VPAC receptor activation.

\section{Discussion}

In the present study, we analyzed by several methods, including time-lapse videomicroscopy, the mechanism by which glial cells secrete and control PN-1 traffic. To address these questions, we constructed a recombinant $\mathrm{PN}-1$ protein that fused its mature $\mathrm{N}$ terminus with GFP (GFP/PN-1) and used this reporter protein as a probe to study post-Golgi exocytotic trafficking and secretion in glial cell cultures. We described for the first time PN-1 trafficking and found that $\mathrm{PN}-1$ release is controlled by reorganization of F-actin cytoskeleton following activation of G-protein-coupled receptors, such as VPAC receptors.

Several serpins have been detected in the brain (Osterwalder et al., 1998). Some of them are mainly secreted by neurons such as neuroserpin (Osterwalder et al., 1998) and others, phosphatidylethanolamine-binding protein by glial cells (Lafon-Cazal et al., 2003) and PN-1 by both cell types (Reinhard et al., 1994). Neuroserpin is associated to dense-core granules and could follow a regulated secretory pathway (Osterwalder et al., 1998). To date, there is no evidence for a regulated secretion of serpins in glial cells. However, hippocampal astrocytes appear to express two classical secretory pathways, constitutive and regulated, respectively (Calegari et al., 1999; Volknandt, 2002).

We found that GFP/PN-1 secretion followed a constitutive secretory pathway, operating via small vesicles, which were not stored along the plasma membrane. This contrasts with the clas- 


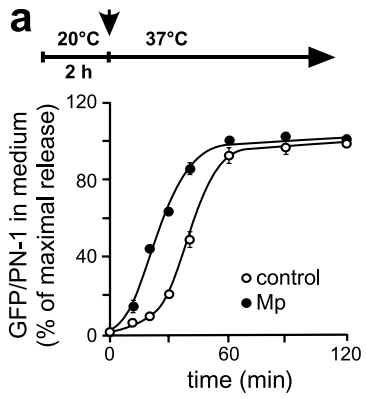

b
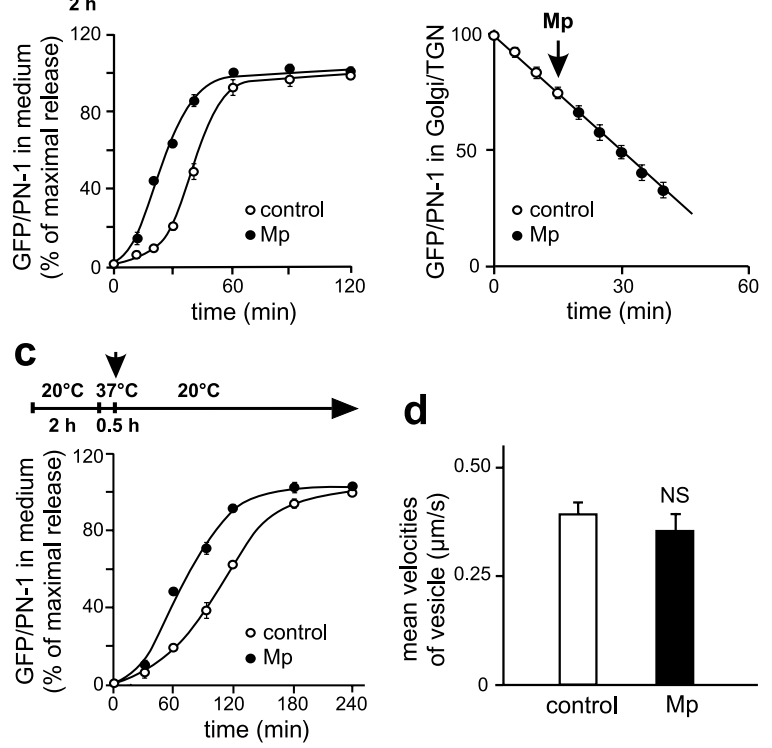

e
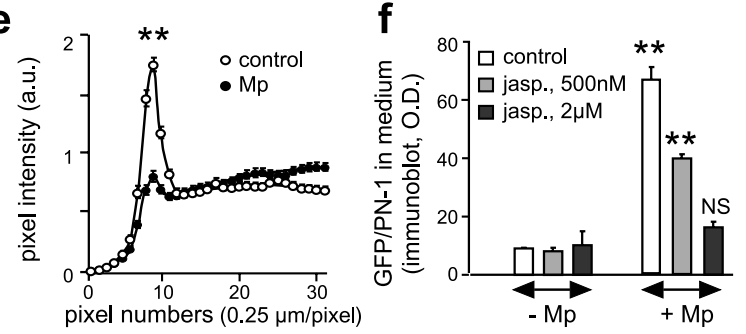

Figure 7. Mastoparan enhances GFP/PN-1 vesicle exocytosis by cortical F-actin disassembly. $\boldsymbol{a}$, Effects of mastoparan on GFP/PN-1 secretion kinetics. Amounts of GFP/PN-1 were determined in media collected at indicated time intervals (arrow; $20 \mu \mathrm{m}$ mastoparan addition). Data are expressed as percentage of maximal release, and error bars represent SEM. Secretion kinetics representative of three independent experiments is shown. $\boldsymbol{b}$, Effects of mastoparan on GFP/PN-1 exit-rate from Golgi/TGN. The exit of post-Golgi vesicles was recorded at 5 min intervals over $40 \mathrm{~min}$, and mastoparan was added $15 \mathrm{~min}$ after the beginning of vesicle exit $(t=0)$. Data are expressed as a percentage of Golgi/TGN fluorescence at time 0 and plotted as a function of time ( $n=23$ cells from 3 experiments; error bars represent SEM). c, Mastoparan increases GFP/PN-1 secretion subsequently to the exit of a transient pool of vesicles from Golgi/TGN. A transient pool of GFP/PN-1 vesicles obtained after temperature block $\left(20^{\circ} \mathrm{C} ; 2 \mathrm{~h}\right)$, release $\left(37^{\circ} \mathrm{C}\right.$ $30 \mathrm{~min})$, and block $\left(20^{\circ} \mathrm{C}\right)$ was followed by the secretion of their content in the absence (control) and presence of $20 \mu \mathrm{m}$ mastoparan (arrow; mastoparan addition). Amounts of GFP/PN-1 were determined and expressed as in $\boldsymbol{a}$. Secretion kinetics representative of four independent experiments is shown. $\boldsymbol{d}$, Mastoparan does not increase the transport of GFP/PN-1 vesicles. Accumulated GFP/PN-1 in TGN was released after a temperature block in the absence of mastoparan for the first $20 \mathrm{~min}$ (control) and then in its presence $(20 \mu \mathrm{M})$ after $40 \mathrm{~min}(\mathrm{Mp})$. Tracks from displacement of post-TGN vesicles containing GFP/PN-1 were analyzed, and velocities were determined as described in Materials and Methods. From every cell ( $n=10$ cells), five to seven tracks were analyzed before and after adding mastoparan. Data are expressed as the mean velocities of vesicles moving along tracks, and error bars represent SEM. NS indicates a nonsignificant difference compared with control condition ( $t$ test).e, Mastoparan induced depolymerization of cortical F-actin. Cells were incubated in the absence (control) or presence of $20 \mu \mathrm{m}$ mastoparan for $15 \mathrm{~min}$, fixed, and stained with rhodamine-labeled phalloidin and Hoechst 33258. The intensity profiles of radial scan lines (see Materials and Methods) were pooled to form a mean profile \pm SEM ( $n=35$ cells; 3 experiments). Data are expressed as pixel intensity in accordance with pixel numbers $(0.25 \mu \mathrm{m} / \mathrm{pixel})$. Asterisks represent a significant difference compared with control condition ( $t$ test; $\left.{ }^{* *} p<0.01\right)$. $\boldsymbol{f}$, Jasplakinolide inhibited mastoparanstimulated secretion of GFP/PN-1. After the temperature block, GFP/PN-1 secretion was measured with or without $20 \mu \mathrm{M} \mathrm{Mp}$ and in the absence (control) or presence of jasplakinolide (jasp.). This permeant actin-stabilizing compound was added at indicated concentrations 5 min before the end of temperature-induced block and for the $30 \mathrm{~min}$ of GFP/PN-1 secretion. Asterisks represent a significant difference, and NS represents a nonsignificant difference, compared with conditions without Mp ( $t$ test; ${ }^{* *} p<0.01$ ), and error bars represent SEM. Secretion inhibition, representative of three independent experiments, is shown. 0.D., Optical density. sical regulated secretory pathway in which dense-core vesicles are stored until a specific signal evokes their exocytosis. However, $\mathrm{GFP} / \mathrm{PN}-1$ secretion is regulated at its final stage by a G-proteincoupled receptor-dependent step, indicating that this secretion belongs to receptor-mediated constitutive secretions. Evidence of a receptor-mediated regulation of the constitutive secretory pathway has been described previously (Luini and De Matteis, 1993). Our data suggest that the PN-1 secretory pathway follows this type of secretion.

GFP/PN-1 traveled through the secretory pathway (reticulum, Golgi/TGN), as expected for a secreted glycoprotein possessing a signal peptide. GFP/PN-1-containing carriers appeared only as small vesicles in both transfected astrocytes in primary culture and glial cell lines. This contrasts with results obtained with vesicular stomatitis virus glycoprotein/GFP (Hirschberg et al., 1998; Toomre et al., 1999) or GFP-tagged membrane proteins in neuronal axons (Nakata et al., 1998; Kaether et al., 2000) that appeared, in majority, as tubules. These differences could be attributable to either the cell type or the location of the protein (membrane-bound vs lumenal proteins) (Toomre et al., 1999).

GFP/PN-1-containing vesicles were transported from the TGN to the plasma membrane along tracks in a discontinuous movement. This movement is composed of rapid runs, pauses, and changes in direction. Movement occurs at maximal and average speeds of $\sim 1$ and $\sim 0.4 \mu \mathrm{m} / \mathrm{s}$, respectively. These values are consistent with that of 0.3-1 $\mu \mathrm{m} / \mathrm{s}$ from other studies (Hirschberg et al., 1998; Nakata et al., 1998; Toomre et al., 1999; Kaether et al., 2000). Moreover, these values are compatible with speed of motors such as kinesins, which drive vesicles along microtubule tracks (Hirokawa, 1998; Goldstein and Yang, 2000).

Depolymerization of microtubules induced changes in the profile of vesicle elementary speeds by decreasing either duration of long runs or maximal speed. This disassembly was followed by a decrease in GFP/PN-1 secretion. This suggested that microtubules are used as tracks to transport GFP/PN-1 containers and that translocation was not a simple random diffusion. However, disruption of microtubules is known to induce both fragmentation and redistribution of Golgi stacks (Storrie et al., 1998) that may either modify kinetics from TGN sorting or decrease GFP/ PN-1 secretion.

To tackle this problem, we used a more direct approach by labeling microtubules with $\beta$-tubulin/DsRed and imaging of double-transfected cells ( $\beta$-tubulin/DsRed and GFP/PN-1) to directly visualize vesicle movements along microtubules. Using this technique, we showed that vesicles moved along microtubules, stopped, remained associated or close, and switched tracks during movement. Thus, GFP/PN-1 vesicle transport proceeds along microtubules, probably using motors (kinesins and dyneins) driving a predominant vesicular flow from the center to the cell periphery, despite its stochastic appearance.

In addition to microtubules that served as tracks for longrange transport, actin cytoskeleton and myosins are also implicated in vesicular transport. In this case, displacements are shorter, and actin-based transport is slower $(\sim 0.1 \mu \mathrm{m} / \mathrm{s})$ than translocation along microtubules (Wu et al., 2000). In astrocytes, during endocytotic and recycling events, membrane-bound type II deiodinase is transported by myosin $\mathrm{Va}$ along actin tracks (Stachelek et al., 2001). In contrast, time-lapse imaging did not show any clear movements of GFP/PN-1-containing vesicles along F-actin fibers in cells expressing both EYFP/actin and GFP/ $\mathrm{PN}-1$. Finally, the myosin inhibitor, BDM did not modify the secretion of GFP/PN-1. This confirms that myosin motors are not involved in GFP/PN-1 post-Golgi trafficking. Moreover, we 


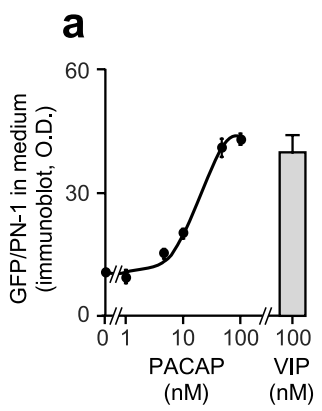

b

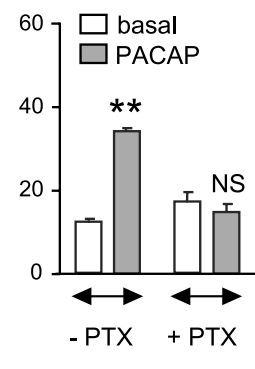

C

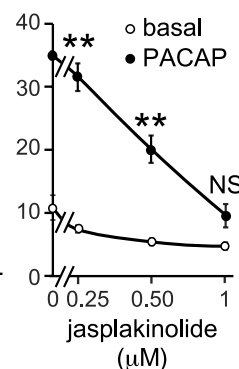

d

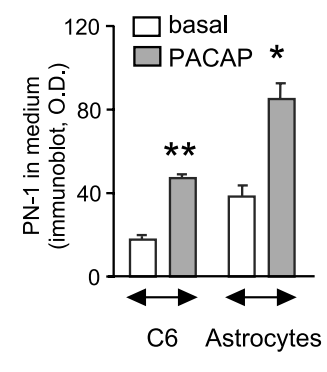

Figure 8. Activation of VPAC receptors induces GFP/PN-1 secretion by F-actin disassembly. $\boldsymbol{a}, \boldsymbol{b}$, PACAP-38 (PACAP) or VIP increases GFP/PN-1 secretion in (6 cells. After a temperature block and release ( 30 min at $\left.37^{\circ} \mathrm{C}\right)$, amounts of GFP/PN-1 were determined in media. Data were expressed as optical densities (0.D.), and error bars represent SEM. $\boldsymbol{a}, \mathrm{GFP} / \mathrm{PN}-1$ secretions from cells under PACAP-38 and VIP stimulations. $\boldsymbol{b}$, Effects of $B$. pertussis toxin cell pretreatment on PACAP-38-induced GFP/PN- 1 secretions. 6 cells were preincubated for $18 \mathrm{~h}$ with $200 \mathrm{ng} / \mathrm{ml}$ B. pertussis toxin (PTX) before temperature block and stimulated in the absence (basal) and presence of $100 \mathrm{~nm}$ PACAP-38. Asterisks represent a significant difference and NS represents a nonsignificant difference compared with basal conditions ( $\left(t\right.$ test; $\left.{ }^{* *} p<0.01\right)$.c, Jasplakinolide inhibited PACAP-38-stimulated secretion of GFP/PN-1 in C 6 cells. After the temperature block, GFP/PN-1 secretion was measured with $100 \mathrm{~nm} \mathrm{PACAP-38} \mathrm{(PACAP)} \mathrm{or} \mathrm{without} \mathrm{(basal)} \mathrm{in} \mathrm{the} \mathrm{presence} \mathrm{of} \mathrm{jasplakinolide.} \mathrm{This} \mathrm{analog} \mathrm{of}$ phalloidin was added at indicated concentrations 5 min before the en d of temperature-induced block and for 30 min of GFP/PN- 1 secretion. Asterisks represent a significant difference, and NS represents a nonsignificant difference, compared with basal conditions $\left(t\right.$ test; ${ }^{* *} p<$ 0.01 ), and error bars represent SEM. Secretion inhibition, representative of three independent experiments, is shown. $\boldsymbol{d}, \mathrm{PN}-1$ secretions from $\left(6\right.$ cells and striatal astrocytes under PACAP-38 stimulation. After the temperature block and release ( 30 min at $\left.37^{\circ} \mathrm{C}\right), \mathrm{PN}-1$ secretion was measured with $100 \mathrm{~nm}$ PACAP-38 (PACAP) or without (basal). Asterisks represent a significant difference compared with basal conditions ( $t$ test; $\left.{ }^{*} p<0.05 ;{ }^{* *} p<0.01\right)$, and error bars represent SEM. Secretion stimulation, representative of three independent experiments, is shown.

detected no bursts of actin polymerization at vesicles carrying GFP/PN-1, such as previously reported during endocytic events in cultured mast cells (Merrifield et al., 1999), cell sorting of viruses (Rietdorf et al., 2001), and propulsion of Listeria in infected cells (Cossart, 2002). Thus, the actin cytoskeleton is not used as a track or a propulsion force to drive transport of GFP/ $\mathrm{PN}$-1-containing vesicles.

Imaging on fixed and live cells shows an accumulation of GFP/ $\mathrm{PN}$-1-containing vesicles on cortical F-actin, suggesting that F-actin at the cell cortex acts as a physical barrier that hinders vesicular movement. This proposal of an F-actin cortical barrier has been reported previously for dense-core secretory granules in the regulated secretion of chromaffin cells (Trifaro et al., 1992) and mast cells (Norman et al., 1994). In contrast to the regulated secretory pathway, there is little evidence for the involvement of actin in the constitutive secretory pathway in mammal cells (Hirschberg et al., 1998). Generally, F-actin disruption failed to affect constitutive secretion and did not affect kinetics of postGolgi transport (Salas et al., 1986).

In contrast, $\mathrm{GFP} / \mathrm{PN}-1$ secretion was enhanced by cytochala$\sin \mathrm{D}$ and latrunculin B treatment. Furthermore, we showed that mastoparan was able to disrupt cortical F-actin-promoting exocytosis without affecting vesicular budding or transport. This effect was prevented by jasplakinolide, an analog of phalloidin that stabilizes F-actin bundles. Similar effects were obtained by activation of VPAC receptors coupled to Gi/Go-proteins. Together, these results indicate that cortical F-actin hinders movement of vesicles and behaves as an obstacle to vesicle docking and fusion. Removal of this obstacle by cytochalasin D, latrunculin B, VPAC receptor activation, and mastoparan allows GFP/PN-1containing vesicles to dock and fuse to plasma membraneenhancing secretion of GFP/PN-1. Thus, cortical F-actin acts as a barrier in both constitutive and regulated secretions. However, in constitutive secretion, vesicles are not stored and embedded in the cortical F-actin network, like granules in regulated secretion (Lang et al., 2000).
$\mathrm{PN}-1$ is the most potent thrombin inhibitor in the brain, but it can also form complexes with plasmin, tissue, and urokinase plasminogen activators and trypsin (Reinhard et al., 1994; Gingrich and Traynelis, 2000). Apart from regulation by de novo biosynthesis (Vaughan and Cunningham, 1993), PN-1 secretion appears to be regulated by activated G-coupled receptors, such as VIP receptors (Festoff et al., 1996). Here, we show that activation of VPAC receptors coupled to heterotrimeric Gi/Go-proteins is able to control exocytosis of GFP/PN-1 in C6 glioma cells. Furthermore, PACAP induced PN-1 secretion in both cultures of C6 glioma cells and striatal astrocytes, indicating that glial cells possess a receptormediated regulation of $\mathrm{PN}-1$ constitutive secretion that is triggered after VPAC receptor activation. The receptor-mediated regulation of secretion provides a way to adapt serpin release and modulate proteolytic activity in the glial cell environment. In particular, this regulation could represent an efficient mechanism to control extracellular thrombin activity and activation of protease-activated receptors, such as PAR-1 that trigger important changes in actin polymerization (Gingrich and Traynelis, 2000). Thus, this mechanism might operate in the regulation of dynamic changes during neurite outgrowth and in the extracellular matrix components during neural plasticity in developing or mature brain (Turgeon and Houenou, 1997; Gingrich and Traynelis, 2000). Furthermore, $\mathrm{PN}-1$ is localized in the perivascular endfeet of glial cells, suggesting that $\mathrm{PN}-1$ is well positioned to counteract extravasated thrombin (Gingrich and Traynelis, 2000). Such a receptor-mediated regulation of secretion might promote a rapid release of antiproteases, counteracting the deleterious effects of extravasated proteases after brain trauma.

In conclusion, our study provides for the first time an extensive characterization of a regulated secretory pathway involved in the release of PN-1 (and possibly other serpins). This process may contribute to the adaptation of extracellular proteolytic activity in response to synaptic activity.

\section{References}

Araque A, Perea G (2004) Glial modulation of synaptic transmission in culture. Glia 47:241-248.

Baker JB, Low DA, Simmer RL, Cunningham DD (1980) Protease-nexin: a cellular component that links thrombin and plasminogen activator and mediates their binding to cells. Cell 21:37-45.

Barres BA (2003) What is a glial cell? Glia 43:4-5.

Bezzi P, Gundersen V, Galbete JL, Seifert G, Steinhäuser C, Pilati E, Volterra A (2004) Astrocytes contain a vesicular compartment that it is competent for regulated exocytosis of glutamate. Nat Neurosci 7:613-620.

Blondel O, Collin C, McCarran WJ, Zhu S, Zamostiano R, Gozes I, Brenneman DE, McKay RD (2000) A glia-derived signal regulating neuronal differentiation. J Neurosci 20:8012-8020.

Calegari F, Coco S, Taverna E, Bassetti M, Verderio C, Corradi N, Matteoli M, Rosa P (1999) A regulated secretory pathway in cultured hippocampal astrocytes. J Biol Chem 274:22539-22547.

Cossart P (2002) Molecular and cellular basis of the infection by Listeria monocytogenes: an overview. Int J Med Microbiol 291:401-409.

Dorner AJ, Wasley LC, Kaufman RJ (1989) Increased synthesis of secreted proteins induces expression of glucose-regulated proteins in butyratetreated Chinese hamster ovary cells. J Biol Chem 264:20602-20607. 
el-Etr M, Cordier J, Glowinski J, Premont J (1989) A neuroglial cooperativity is required for the potentiation by 2 -chloroadenosine of the muscarinicsensitive phospholipase C in the striatum. J Neurosci 9:1473-1480.

Espinosa de los Monteros A, Kumar S, Scully S, Cole R, de Vellis J (1990) Transferrin gene expression and secretion by rat brain cells in vitro. J Neurosci Res 25:576-580.

Festoff BW, Nelson PG, Brenneman DE (1996) Prevention of activitydependent neuronal death: vasoactive intestinal polypeptide stimulates astrocytes to secrete the thrombin-inhibiting neurotrophic serpin, protease nexin I. J Neurobiol 30:255-266.

Gingrich MB, Traynelis SF (2000) Serine proteases and brain damage-is there a link? Trends Neurosci 23:399-407.

Girotti M, Banting G (1996) TGN38-green fluorescent protein hybrid proteins expressed in stably transfected eukaryotic cells provide a tool for the real-time, in vivo study of membrane traffic pathways and suggest a possible role for ratTGN38. J Cell Sci 109:2915-2926.

Gloor S, Odink K, Guenther J, Nick H, Monard D (1986) A glia-derived neurite promoting factor with protease inhibitory activity belongs to the protease nexins. Cell 47:687-693.

Goldstein LS, Yang Z (2000) Microtubule-based transport systems in neurons: the roles of kinesins and dyneins. Annu Rev Neurosci 23:39-71.

Gurwitz D, Cunningham DD (1988) Thrombin modulates and reverses neuroblastoma neurite outgrowth. Proc Natl Acad Sci USA 85:3440-3444.

Higashijima T, Uzu S, Nakajima T, Ross EM (1988) Mastoparan, a peptide toxin from wasp venom, mimics receptors by activating GTP-binding regulatory proteins (G proteins). J Biol Chem 263:6491-6494.

Higashijima T, Burnier J, Ross EM (1990) Regulation of Gi and Go by mastoparan, related amphiphilic peptides, and hydrophobic amines. Mechanism and structural determinants of activity. J Biol Chem 265:14176-14186.

Hirokawa N (1998) Kinesin and dynein superfamily proteins and the mechanism of organelle transport. Science 279:519-526.

Hirschberg K, Miller CM, Ellenberg J, Presley JF, Siggia ED, Phair RD, Lippincott-Schwartz J (1998) Kinetic analysis of secretory protein traffic and characterization of Golgi to plasma membrane transport intermediates in living cells. J Cell Biol 143:1485-1503.

Kaether C, Skehel P, Dotti CG (2000) Axonal membrane proteins are transported in distinct carriers: a two-color video microscopy study in cultured hippocampal neurons. Mol Biol Cell 11:1213-1224.

Knauer DJ, Majumdar D, Fong PC, Knauer MF (2000) SERPIN regulation of factor XIa. The novel observation that protease nexin 1 in the presence of heparin is a more potent inhibitor of factor XIa than $\mathrm{C} 1$ inhibitor. J Biol Chem 275:37340-37346.

Kreitzer G, Marmorstein A, Okamoto P, Vallee R, Rodriguez-Boulan E (2000) Kinesin and dynamin are required for post-Golgi transport of a plasma-membrane protein. Nat Cell Biol 2:125-127.

Krzan M, Stenovec M, Kreft M, Pangrsic T, Grilc S, Haydon PG, Zorec R (2003) Calcium-dependent exocytosis of atrial natriuretic peptide from astrocytes. J Neurosci 23:1580-1583.

Lafon-Cazal M, Adjali O, Galeotti N, Poncet J, Jouin P, Homburger V, Bockaert J, Marin P (2003) Proteomic analysis of astrocytic secretion in the mouse. Comparison with the cerebrospinal fluid proteome. J Biol Chem 278:24438-24448.

Lagriffoul A, Charpentier N, Carrette J, Tougard C, Bockaert J, Homburger V (1996) Secretion of protease nexin-1 by C6 glioma cells is under the control of a heterotrimeric G protein, Gol. J Biol Chem 271:31508-31516.

Lang T, Wacker I, Wunderlich I, Rohrbach A, Giese G, Soldati T, Almers W (2000) Role of actin cortex in the subplasmalemmal transport of secretory granules in PC-12 cells. Biophys J 78:2863-2877.

Luini A, De Matteis MA (1993) Receptor-mediated regulation of constitutive secretion. Trends Cell Biol 3:290-292.

Luthi A, Van der Putten H, Botteri FM, Mansuy IM, Meins M, Frey U, Sansig G, Portet C, Schmutz M, Schroder M, Nitsch C, Laurent JP, Monard D (1997) Endogenous serine protease inhibitor modulates epileptic activity and hippocampal long-term potentiation. J Neurosci 17:4688-4699.

Meins M, Piosik P, Schaeren-Wiemers N, Franzoni S, Troncoso E, Kiss JZ, Brosamle C, Schwab ME, Molnar Z, Monard D (2001) Progressive neuronal and motor dysfunction in mice overexpressing the serine protease inhibitor protease nexin-1 in postmitotic neurons. J Neurosci 21:8830-8841.

Merrifield CJ, Moss SE, Ballestrem C, Imhof BA, Giese G, Wunderlich I, Almers W (1999) Endocytic vesicles move at the tips of actin tails in cultured mast cells. Nat Cell Biol 1:72-74.
Molinari F, Meskanaite V, Munnich A, Sonderegger P, Colleaux L (2003) Extracellular proteases and their inhibitors in genetic diseases of the central nervous system. Hum Mol Genet 12:R195-R200.

Murai KK, Nguyen LN, Irie F, Yamaguchi Y, Pasquale EB (2003) Control of hippocampal dendritic spine morphology through ephrin-A3/EphA4 signaling. Nat Neurosci 6:153-160.

Nakata T, Terada S, Hirokawa N (1998) Visualization of the dynamics of synaptic vesicle and plasma membrane proteins in living axons. J Cell Biol 140:659-674

Norman JC, Price LS, Ridley AJ, Hall A, Koffer A (1994) Actin filament organization in activated mast cells is regulated by heterotrimeric and small GTP-binding proteins. J Cell Biol 126:1005-1015.

Osterwalder T, Cinelli P, Baici A, Pennella A, Krueger SR, Schrimpf SP, Meins M, Sonderegger P (1998) The axonally secreted serine proteinase inhibitor, neuroserpin, inhibits plasminogen activators and plasmin but not thrombin. J Biol Chem 273:2312-2321.

Pfrieger FW, Barres BA (1997) Synaptic efficacy enhanced by glial cells in vitro. Science 277:1684-1687.

Reinhard E, Suidan HS, Pavlik A, Monard D (1994) Glia-derived nexin/ protease nexin-1 is expressed by a subset of neurons in the rat brain. J Neurosci Res 37:256-270.

Rietdorf J, Ploubidou A, Reckmann I, Holmstrom A, Frischknecht F, Zettl M, Zimmermann T, Way M (2001) Kinesin-dependent movement on microtubules precedes actin-based motility of vaccinia virus. Nat Cell Biol 3:992-1000.

Salas PJ, Misek DE, Vega-Salas DE, Gundersen D, Cereijido M, RodriguezBoulan E (1986) Microtubules and actin filaments are not critically involved in the biogenesis of epithelial cell surface polarity. J Cell Biol 102:1853-1867.

Slezak M, Pfrieger FW (2003) New roles for astrocytes: regulation of CNS synaptogenesis. Trends Neurosci 26:531-535.

Smith-Swintosky VL, Zimmer S, Fenton Jr JW, Mattson MP (1995) Protease nexin-1 and thrombin modulate neuronal $\mathrm{Ca}^{2+}$ homeostasis and sensitivity to glucose deprivation-induced injury. J Neurosci 15:5840-5850.

Specht H, Peterziel H, Bajohrs M, Gerdes HH, Krieglstein K, Unsicker K (2003) Transforming growth factor beta2 is released from PC12 cells via the regulated pathway of secretion. Mol Cell Neurosci 22:75-86.

Stachelek SJ, Tuft RA, Lifschitz LM, Leonard DM, Farwell AP, Leonard JL (2001) Real-time visualization of processive myosin 5a-mediated vesicle movement in living astrocytes. J Biol Chem 276:35652-35659.

Storrie B, White J, Rottger S, Stelzer EH, Suganuma T, Nilsson T (1998) Recycling of Golgi-resident glycosyltransferases through the ER reveals a novel pathway and provides an explanation for nocodazole-induced Golgi scattering. J Cell Biol 143:1505-1521.

Suidan HS, Stone SR, Hemmings BA, Monard D (1992) Thrombin causes neurite retraction in neuronal cells through activation of cell surface receptors. Neuron 8:363-375.

Tomimatsu Y, Idemoto S, Moriguchi S, Watanabe S, Nakanishi H (2002) Proteases involved in long-term potentiation. Life Sci 72:355-361.

Toomre D, Keller P, White J, Olivo JC, Simons K (1999) Dual-color visualization of trans-Golgi network to plasma membrane traffic along microtubules in living cells. J Cell Sci 112:21-33.

Trifaro JM, Rodriguez del Castillo A, Vitale ML (1992) Dynamic changes in chromaffin cell cytoskeleton as prelude to exocytosis. Mol Neurobiol 6:339-358.

Turgeon VL, Houenou LJ (1997) The role of thrombin-like (serine) proteases in the development, plasticity and pathology of the nervous system. Brain Res Brain Res Rev 25:85-95.

Ullian EM, Christopherson KS, Barres BA (2004) Role for glia in synaptogenesis. Glia 47:209-216.

Vaughan PJ, Cunningham DD (1993) Regulation of protease nexin-1 synthesis and secretion in cultured brain cells by injury-related factors. J Biol Chem 268:3720-3727.

Vaughan PJ, Pike CJ, Cotman CW, Cunningham DD (1995) Thrombin receptor activation protects neurons and astrocytes from cell death produced by environmental insults. J Neurosci 15:5389-5401.

Volknandt W (2002) Vesicular release mechanisms in astrocytic signalling. Neurochem Int 41:301.

Wu X, Jung G, Hammer III JA (2000) Functions of unconventional myosins. Curr Opin Cell Biol 12:42-51. 